\title{
STRIKING THE BALANCE: THE ROLE OF ENGLISH AND GERMAN IN A MULTILINGUAL ENGLISH-MEDIUM DEGREE PROGRAMME IN GERMAN HIGHER EDUCATION.
}

Clive W. Earls

Maynooth University, National University of Ireland Maynooth

In 2002, English-medium degree programmes became a permanent feature of German higher education. While this action marked an important step towards government-supported institutionalisation of English in Germany no formal strategy or guidelines governing the role of English in higher education has been developed. To date, research in this area in Germany has been predominantly focussed on the top-down perspectives of decision-makers (see Dunst, 2005; Voegeli, 2005; Lub et al, 2003); comparatively few studies have been conducted into bottom-up perspectives of those directly experiencing such language policy and planning decisions. In this paper, empirical data resulting from a mixed-method case study conducted at a German higher education institution shall be analysed to reveal hitherto unexplored bottom-up insights into the lived reality of an English-medium degree programme in Germany. The paper begins with an introduction to such programmes in Germany, before outlining the methodology pursued and exploring demographics and participant motivations within the programme under investigation. Applying Spolsky's (2004, p. 39) framework for analysing language policy, the de facto language policy experienced by study participants is revealed, providing insights into daily linguistic practices within the programme, and the pragmatic and ideological roles that English and German play in participants' reported experiences. Uncovering this de facto language policy serves to provide policymakers at top-down level with bottom-up perspectives for future policy formulation which may lead to a more valid language policy (Shohamy, 2009, p. 188).

Key Words: language-in-education policy; English-medium degree programmes; German as an international language; English as a global language; language ecology; language ideologies 


\section{English-medium degree programmes in Germany: Origins \& current state of affairs}

English-medium degree programmes (EMDPs) are a phenomenon spreading rapidly throughout Europe's higher education (HE) systems (Cots, 2013; Doiz, Lasagabaster \& Sierra, 2011; Maiworm \& Wächter, 2008). Research in the area is expanding rapidly in view of the fact that English-medium education higher education is less researched in European contexts rather than post-colonial contexts (c.f. Harlech-Jones, 1990 for Namibia; Krishnamurti, 1990 for India; Tung, Lam \& Tsang, 1997 and Tsui (2008) for Hong Kong; Uys et al, 2007 for South Africa). While Scandinavian countries and the Netherlands have actively been introducing EMDPs since the 1980s, predating all other European countries (Coleman, 2006), from 2002 Germany began to pursue the introduction of such programmes with great momentum and is now only second to the Netherlands as Europe's leader in providing EMDPs at Bachelor and Masters level (Nuffic, 2011; DAAD, 2011; SIS, 2011). In Germany, the move towards English-medium education began in 1996 with a pilot project to test the potential of EMDPs as a driver of internationalisation in the HE sector (DAAD \& HRK, 2001). In 2002, it was deemed successful and EMDPs were adopted as a permanent feature of German HE.

Internationalisation is now seen as a key component in the survival of higher education institutions (HEIs) (DAAD, 2008, p. 2; Coleman, 2006). For non-English-speaking European countries, the use of their national language as the medium of instruction in HE is perceived as a barrier to internationalisation. In view of this, such countries are undertaking a process of introducing EMDPs as a means of overcoming any competitive disadvantage resulting from their linguistic situation (Maiworm \& Wächter, 2008, p. 15; Hughes, 2008, p. 119), as English is perceived as the most widely used language of communication (Crystal, 1997; Graddol, 1997). Internationalisation has, therefore, become synonymous with the introduction of EMDPs (Phillipson, 2008, p. 4; Marsh \& Laitinen, 2005; DAAD, 2002) manifested directly in the German Federal Government's motto “Brain Gain statt [instead of] Brain Drain” (BMBF, 2000a; 2000b; 2001). This campaign describes the role that EMDPs play in retaining domestic students, and accessing the steady flow of international students who were increasingly bypassing Germany (Hellmann \& Pätzold, 2005), and the goal of retaining such students after HE study. Germany's lack of competitiveness in the 1980's, 1990's and early 2000's as a study location 
was attributed to a number of obstacles identified as early as 1966 by the German Science Council (Wissenschaftsrat) ${ }^{\mathrm{i}}$.

The German Academic Exchange Service (DAAD) is charged with the management and promotion of international degree programmes (IDPs ${ }^{\mathrm{ii}}$ ). For a programme to qualify as an IDP under the auspices of the DAAD, certain criteria must be met - namely, the use of English as the partial or full language of instruction, an internationalised curriculum ${ }^{\text {iii }}$ with integrated study periods abroad, the offer of an internationally recognised qualification and support services for students on the programme beyond the study area. The provision of IDPs in Germany has risen considerably in recent years and continues to rise. In 2009, the number of DAAD-certified IDPs offered at undergraduate and postgraduate levels in Germany totalled 505, with this number growing to 748 in 2011, an increase of $48 \%$. IDPs can be sub-divided into three categories based on their language(s)-of-instruction: English-only programmes (EMDPs), mixed German and English programmes and English-to-German phased programmes ${ }^{\text {iv }}$. English-only programmes have English as the sole language of instruction, while mixed-language programmes offer a certain proportion of the modules in English and German with many operating on a 50\%-50\% or $60 \%-40 \%$ model. In English-to-German phased programmes, students begin their degree programmes studying entirely through the medium of English for one to two years and receive intensive tuition in German so as to transition to receive their entire tuition in German for the remaining two years of their studies. A clear preference for EMDPs at postgraduate level is observable with a 6:1 ratio of Masters to Bachelor programmes. Additionally, while almost all Masters programmes are offered following the English-only model, Bachelor programmes are evenly split into English-only, and mixed English- and German-medium programmes (DAAD, 2011).

The main research aims of this study relate to generating demographical data on student and faculty involved in the EMDP under investigation in addition to assessing motivations behind the choice to pursue/become involved in an EMDP within a German-speaking macrocosm. Furthermore, the study aims to uncover implicit and explicit attitudes towards, and ideologies surrounding, English and German and to ascertain the extent to which such attitudes are reflected in, and conflict with, participants' practices both within and outside the classroom, Published in: Current Issues in Language Planning 15(2) 153-173 
and the effects of such on the programme environment. Employing the dominant framework of a working theory of language policy (Spolsky, 2004), all of these considerations are unified in order to uncover the de facto, experienced reality of bottom-up actors within an EMDP programme in Germany to serve as input into future policy formulation.

\section{Methodology}

The research design adopted for this study integrated elements from 'evaluative' (Stenhouse, 1988) and 'illuminative' (Parlett \& Hamilton, 1972) case-study approaches. The evaluative dimension pertains to providing decision-makers at institutional, federal and national level with the bottom-up experienced reality within the programme of study under investigation to compare with top-down perspectives of envisaged policy outcomes for future policy formulation in the area of English-medium education. The illuminative dimension addresses the gap in the literature on the lived reality of a Bachelor-level EMDP in Germany in providing a bottom-up perspective to augment the rich literature already present from the top-down perspective.

The research instruments employed for data collection at the study site were questionnaires comprising closed- and open-ended questions, one-to-one semi-structured interviews, and focus groups. The questionnaires provided the data on study participants to be submitted for statistical analysis in addition to preliminary qualitative insights for further exploration in the one-to-one semi-structured interview and focus group stages. One-to-one semi-structured interviews were conducted with members of the teaching faculty to qualify the questionnaire data. Focus groups were held with a cross-section of selected German and international students from second and fourth semesters of study with the same aim. The data analysed in this paper result from methodological triangulation of questionnaires and focus groups in the case of student perspectives, and questionnaires and semi-structured interviews in the case of teaching faculty. Furthermore, a process of dataset triangulation comparing student and teaching faculty cohorts was employed to gain a more complete portrayal of the study environment. 
Employing 'criterion sampling' (Patton, 2002, p. 238), the pool of potential study sites was narrowed from 76 to 4 . The selection criteria applied were that the programmes must be English-only, DAAD-certified IDPs offered at Bachelor level by a publicly-funded HEI. A case study was undertaken at each of these four institutions. The results from one randomly-sampled case study from the pool of 4 aforementioned study sites provide the data for this paper as the study aims to capture and portray a wide array of insights into the inner-workings of an Englishmedium degree programme in Germany with a view to uncovering the context's individual $d e$ facto language policy. The case study examined within this contribution was randomly sampled from the pool of 4 case-study sites identified by means of the aforementioned 'criterion sampling'. The remaining 3 case studies comprise a comparative study which is still ongoing and provides a deeper exploration of the findings emerging from this initial case study.

In 2009, during the first data collection phase, paper-based questionnaires were distributed by the researcher to a randomly-sampled representative 'captive audience' (Gillham, 2000, p. 9) of 36 international and German students $(\mathrm{n}=36)$ in their second and fourth semesters, and of 5 lecturers $(n=5)^{v}$. Having been granted access to matriculation data for the degree programme under investigation, it should be started that this student sample represented $95 \%$ of the total population of students enrolled on the degree programme studied. The second data collection phase comprised one-to-one semi-structured interviews with teaching faculty and focus groups with students. Two one-to-one semi-structured interviews were conducted with members of the teaching faculty $(\mathrm{n}=2)$. Applying stratified random sampling, focus groups comprised a mix of German and international students $(n=14)$. Focus Group 1 (FG1) was conducted with nine students in their second semester (four German and five international students), while five students (three German and two international) in their fourth semester participated in Focus Group 2 (FG2).

The Bachelor-level programme of study under investigation was offered at a publiclyfunded HEI from the Fachhochschule ${ }^{v i}$ sector of the German HE system. It was the sole Englishonly programme offered at the institution and was interdisciplinary in nature, incorporating modules from the disciplines of Science and Technology, and Business Studies In analysing the representative student sample, $76.5 \%$ are categorised as 'international students ${ }^{\text {vii }}$, while only Published in: Current Issues in Language Planning 15(2) 153-173 
$23.5 \%$ are German students. This is an interesting finding in view of the fact that such programmes were designed to actively target a 50:50 ratio of German and international students. The nationality variable amongst international students exhibits a high degree of heterogeneity with only minor clusters discernible. Almost $90 \%$ of students ranked English as their L1 or L2, and $89 \%$ of international students reported that they had spent over a year in Germany prior to commencing their studies rather than coming to Germany for the purposes of study. In assessing motivations for wishing to come to Germany, the most frequently cited reason amongst international students was a 'personal or family connection to Germany' (35.7\%), which indicates that this programme functions as a means of attracting people already associated with Germany or indeed immigrants living in the country wishing to study but lacking German proficiency. The only other concentrations amongst international student motivation for pursuing HE in Germany relates to 'low tuition fees', 'accessing the German and European labour markets' and 'learning German as a foreign language', totalling 10.7\% respectively. Motivation regarding the English-only programme for international students pertained mainly to its function in enabling study in Germany with no German proficiency (60.7\%) coupled with a strong association between English proficiency and career success (71.4\%). German student motivations for pursuing an English-only programme exhibit similarly strong associations between English and career success (50\%), while 'improving English proficiency in unison with acquiring applied knowledge' was the most dominant motivation in this group (75\%).

The teaching faculty sample totalled 5 and although it may appear small, the sample represents $62 \%$ of the total faculty population on the programme of study. All teaching faculty members involved in the English-only programme are German and ranked English as their L2. The majority of teaching faculty who participated (3 of 5) chose the option "no choice but to teach on the programme' as their top reason for programme involvement. This response suggests a lack of interest and active engagement with English-only programmes. Participating teaching faculty did, however, exhibit positive attitudes towards teaching in a multicultural environment and the international orientation of the curriculum (2 of 4). 


\section{Towards a language policy for an EMDP in Germany}

In order to decipher and understand the language policy of any particular context, a number of factors must be considered. Adopting Spolsky's framework for language policy analysis (2004, p. 39), understanding the language policy of an EMDP in Germany hinges upon the identification and exploration of the context under each of the four follwing assumptions:

(a) the extra-linguistic factors acting on the setting; the range of political, economic, social, educational and historical developments that have a bearing on the environment

(b) the speech community (of any size); in the context of this research, students and teaching faculty within an EMDP at a German HEI represent a distinct, clearly defined speech community as their linguistics practices vary quite significantly from those in the macro German-speaking environment of the institution.

(c) the permeation of language policy at all levels from micro (family, institutions) through to macro (nation state or supranational entity), and

(d) a tripartite model of ecology, ideology and planning. Figure 1 is a graphical adaptation of the tripartite model first developed theoretically by Spolsky (2004) and graphically represented by Shohamy (2006).

Building on Shohamy's (2006) linear graphical depiction, the adaptation below (see Figure 1) highlights the reciprocity of the ecology, ideology and planning within the model indicated by the bidirectional arrows.

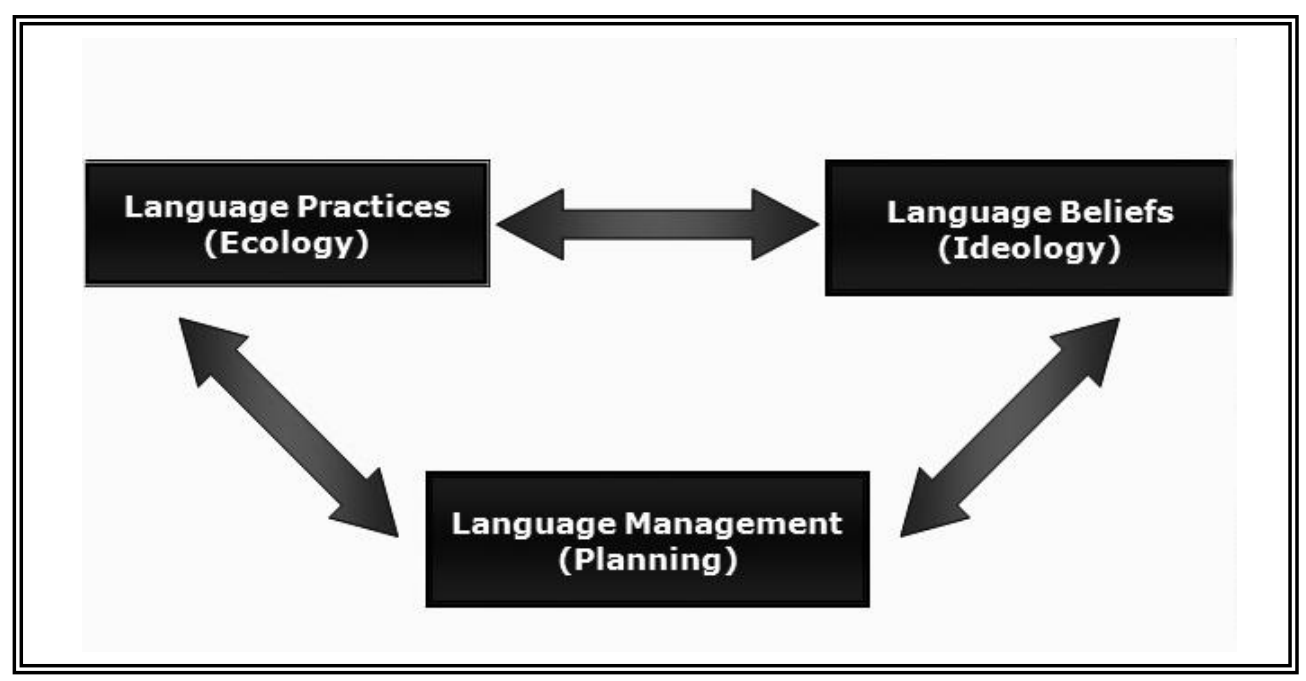

Published in: Current Issues in Language Planning 15(2) 153-173 
Figure 1: A Tripartite Model of Language Policy (adapted from Shohamy, 2006, p.53)

'Planning' denotes the direct intervention in the sociolinguistic setting to manipulate the language situation. A number of factors are seen as influencing the three dimensions in the tripartite model of language policy for an EMDP and equally representing the extra-linguistic frame which underpins the EMDP context in Germany.Figure 2 outlines the array of domestic and international factors which have led to the development of EMDPs in Germany. Equally, such factors represent the extra-linguistic considerations influencing not only the planning dimension to the tripartite model but also the range of ideologies and practices present amongst the study programme's participants).

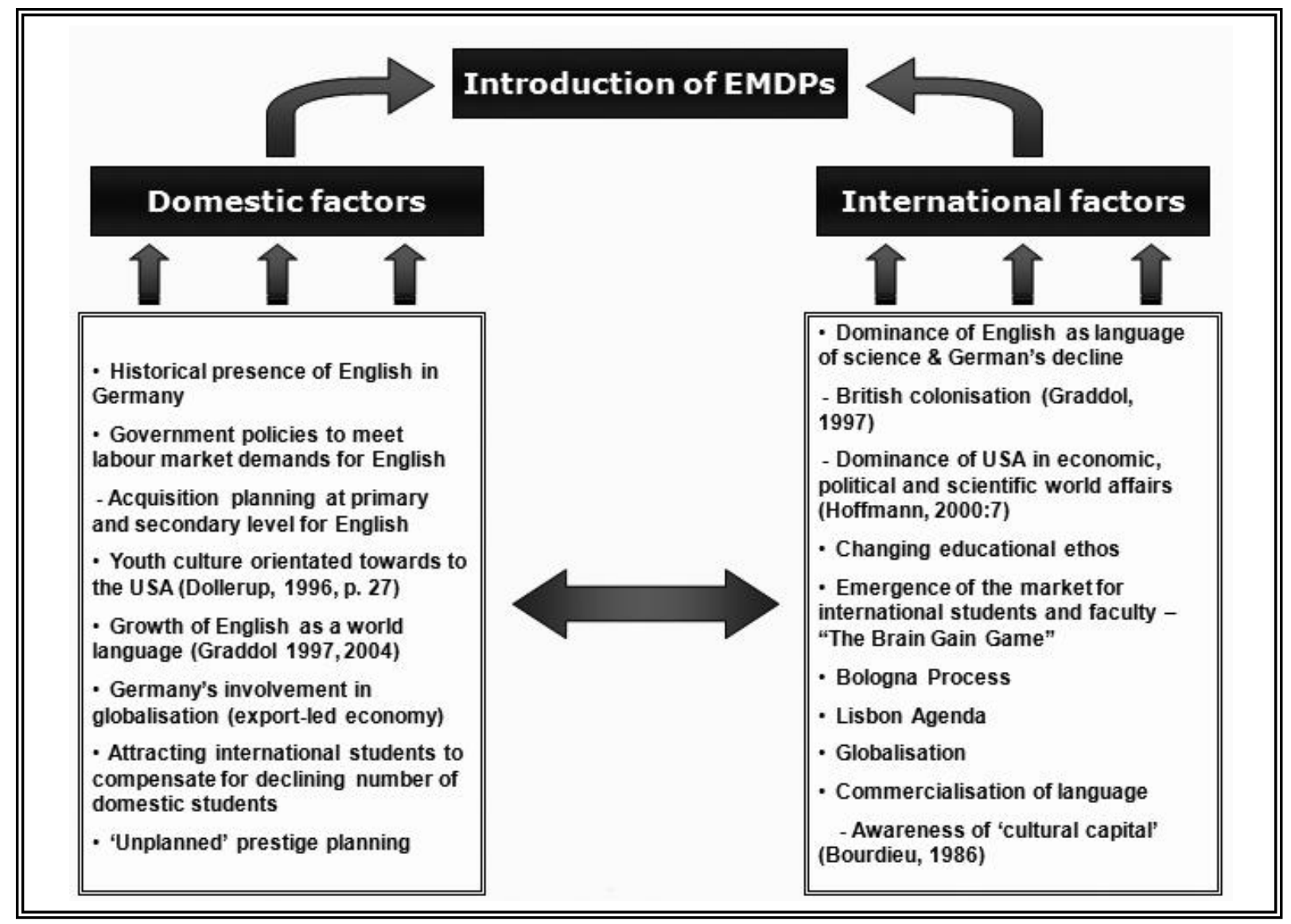

Figure 2: The Extra-Linguistic Considertaions for EMDPs in Germany

Turning to Figure 2, the various domestic and international factors coalescing in the introduction of EMDPs in Germany are now discussed. A process of planned 'acquisition 
planning' (Cooper, 1989, p. 157) to cultivate English proficiency in Germany's secondary education system has been taking place in the country since the establishment of the Federal Republic of Germany following the Second World War in unison with the historical presence of English in German society e.g. a youth culture orientated towards the USA (Dollerup, 1996, p. 27), perception of English-speaking military as liberators rather than invaders (Hagège, 1996, p. 14). This has culminated in English's current status as the first foreign language (Statistisches Bundesamt, 2008a; 2008b; 2011). This planning action is seen as a major factor underpinning the development of EMDPs in Germany. Further educational planning was, and continues to be, enacted today in order to achieve political, economic and educational aims and has crystallised in the form of EMDPs in Germany's HE system. This planning is undertaken in response to an array of concomitant domestic and international developments which are arguably seen as further driving these processes of acquisition and consequently contribute to a process of 'unplanned' (Baldauf, 1994) prestige planning (Haarman, 1990).

Given that Germany is the world's fourth largest economy (IMF, 2011) and its export market is essential to drive economic activity, the country is heavily, enmeshed in and dependent upon the processes of globalisation. English is the most used language worldwide (Crystal, 1997; Graddol, 1997) having established itself as the dominant language of international communication in various domains (Seidlhofer et al., 2006; Graddol, 1997) and consequently as the language of globalisation (Fishman, 1988; Hüppauf, 2004). This dominance is particularly strong within the field of science where English gradually displaced German and French as the dominant media of international communication at the end of the $19^{\text {th }}$ and start of the $20^{\text {th }}$ centuries (Ammon 1995; 1998), accompanying the USA's growing role in world economic and political affairs (Hoffmann, 2000, p. 7). This has impelled Germany to intensify its effort to cultivate English proficiency. A direct manifestation of this is the introduction of EMDPs in Germany as a means of educating its domestic students to drive this process of globalisation. The globalisation of business has contributed significantly to a commodification of language (Heller, 2003), where proficiency in a language is perceived as important 'symbolic capital' (Bourdieu, 1986) as a means to access greater resources and/or employment prospects. This is particularly the case with English (Heller, 2003; 2010; Rahman, 2009) due to its aforementioned anchoring in the processes of globalisation and its perception as the world Published in: Current Issues in Language Planning 15(2) 153-173 
language. With the drive towards knowledge-based economies amongst OECD nations (OECD, 2005), higher education is perceived as pivotal to the production and dissemination of economically-valuable knowledge (Carnoy, 1994). Equally, increased pressure has been exerted on HE by national governments to provide larger proportions of the population with those skills demanded by the labour market (Naidoo \& Jamieson, 2005, p. 38). Furthermore, international students are identified as a means to compensate for the shortfall in the enrolment of domestic students at higher education level to meet the growing need for skilled labour within developed countries (Wilkinson, 2008, p. 169). The adoption of the Lisbon Strategy and its effect on the Bologna process by injecting the economic agenda into the process of harmonising European higher education systems is a further element in the process of commoditising education which has had a large impact on current trends in higher education (Marginson \& Van der Wende, 2006, p. 35). These factors have led to a shift in the perception of HE from a 'public good' to an industry capable of bolstering national competitiveness, and a valuable service to be commoditised and sold in international marketplace (Naidoo, 2003, p. 250). These developments contribute to an increasing commodification of higher education whichis manifested in a changing educational ethos amongst students towards more transactional approaches to education, where their higher education is increasingly perceived as a gateway to employment by means of imparting desired skills rather than a process of developing personally and cognitively (Rickwood \& Goodwin, 1999; Powell, McGuire \& Crawford, 1999). The emergence of internationalisation as the key to survival for HEIs (Coleman, 2006; DAAD, 2008) has also been decisive in driving the introduction of EMDPs in the German HE system due to their potential for accessing the emergent market for international students and staff, and allowing Germany to actively play the 'brain gain' game ${ }^{\text {viii }}$. This process has become so prevalent that internationalisation has become almost synonymous with the introduction of EMDPs in Germany (DAAD, 2002).

\section{The tripartite model: Ecology, ideology and planning}

Returning to the tripartite model (Spolsky, 2004, p. 39) of ecology (language practices), ideology (language beliefs) and management (language planning), it shall now be employed to uncover the de facto language policy in place within the environment studied. Spolsky (2004, p.

Published in: Current Issues in Language Planning 15(2) 153-173 
39) highlights that many contexts have no official, written planning activities so that the nature of their language policy must be derived from the study of their language practices and beliefs. EMDPs have been introduced in Germany without any explicit language-in-education policy at national level, which has allowed for multiple interpretations of such programmes ranging from institution to institution. The only guidelines that could be interpreted as having some bearing on a language policy for EMDPs in Germany are the criteria required for DAAD certification. DAAD-certified EMDPs are subject to a number of structural criteria, two of which address the issue of language: English is the sole language of instruction, exams and assignments; and professional coaching and counselling outside students' degree programme content (i.e. Business Studies), the latter of whichmay be seen to allude to a provision of German as a foreign language considering the pragmatic need for German proficiency amongst international students outside their programme of study. In view of the lack of a formal, written language policy for EMDPs in Germany, their language policies must be derived from a study of the ecology and ideologies within the setting to reveal the de facto language policy of those directly involved in the setting.

The 'ecology' dimension in the tripartite model appears complex in the case of EMDP studies with the multilingual, multicultural composition of the student population being reflected in students' everyday linguistic practices. 'Ecology', or language practices, refers to the interactions between any given language and its environment (Haugen, 1971). Ecology, therefore, plays a central role in understanding the de facto language policy of a speech community as the statuses and ideological values (influenced by extra-linguistic factors) associated with each language within the environment are reflected in its language practices.

Within the EMDP's ecology, a clear divide between international and German students was observed with different languages functioning for inter- and intra-group communication. A high degree of clustering takes place within the programme along common nationality lines so that local/regional languages common to each groups' members are used for intra-group communication. Intergroup communication both between subgroups of international students and between international students and German students unsurprisingly operates through the medium of English, as it is the only language common to the linguistic repertoires of all students within the programme. A lack of German proficiency amongst international students emerges as a 
decisive factor in the division between international and German students. Those international students who possess high proficiency in German $(n=2)$ strongly agree on a Likert scale in the questionnaire and explain in focus groups that they feel more integrated into the Germanspeaking group than those students who do not. Furthermore, international students who are proficient in German and English report in focus groups that they experience greater levels of interaction, movement between, and acceptance in, both groups than those who do not. This would suggest that German functions as the prestige language in the programme denoting integration, and intergroup mobility and acceptance:

International Student 04 (male): The German guys in our course speak German all the time and when they see you want to speak German...(pause)...they will talk to you more and are more interested in you

International Student 27 (male): ...because it's very difficult to communicate not only on campus but the society as a whole without German...(pause)...I noticed people are...(pause)...friendlier and want to talk to me when I speak German not English

German student 06 (female): It's just easier if they [international students] speak German because then we can talk outside of class and don't have to translate everything into English...(pause)...it makes sense because they are living in Germany so...(pause)...they should know German language and culture.

While English represents the common language for communication within the context, during focus group interactions, semi-structured interviews and in the open-ended portion of the questionnaire study participants report issues of intelligibility through the medium of English based on two reasons: a large number of non-native ${ }^{\mathrm{ix}}$ varieties of English due to the large international student population and differences in proficiency levels. In discursively analysing focus group transcripts and open-ended questionnaire responses, it emerges that many students associate English with native-speaker norms in speaking about their desire for more exposure to English outside their degree programmes and in assessing their teaching faculties English abilities.Students, therefore, highlight the challenge of intelligibility posed by this non-native, multi-varietal English-speaking environment on a day-to-day basis. This issue is also mirrored in teaching faculty qualitative data emerging from semi-structured interviews.ABoth students and faculty admit that many African and Asian varieties of English used in their environment are unintelligible to them which often leads to miscommunication. German students also discuss this 
issue of intelligibility to a lesser extent due to their decreased exposure to the international students on the programme. They do, however,reveal that English varieties pose an impediment to, and discouragement from, interacting with such international students. Teaching faculty highlight that, in order to combat these intelligibility issues, efforts are actively being made to create some convergence in proficiency levels and varieties through the introduction of specific English for Communication modules devised to create common agreed linguistic repertoires and norms in English within the environment studied in order to mitigate miscommunication and allow the English as the medium of instruction model to function more effectively:

Teaching faculty 03 (female): It must be admitted that problems happen with students from...(pause)...Africa and Asia because their English is...(pause)...just not what we know. What they understand about English is not what we [Germans]...(pause)...understand so in class I have problems understanding what they are saying.

Teaching faculty 01 (female): Well because we have so many different types of English in the programme...(pause)...what I try to do in my classes is to bring all the variation together...(pause)...and try to agree on similarities with students so that everyone can...(pause)...understand what each other is saying. It makes teaching and learning a lot easier to have agreed norms for...(pause)...the English used in the classroom.

German student 04 (male): I'm listening to them and I'm like seriously...(pause)...is that English? Really?...(pause)...that can't be English. My English is already quite good but I just have no clue what this guy from Africa and this girl from India say in class...and you can see the teacher is...(pause)...having a problem too so it's a real challenge.

Perceptions of English usage within the classroom exhibit similarities across participant groups. Such perceptions highlight issues of student and particularly teaching faculty English proficiency, mirroring findings noted in other European contexts (c.f. Fandrych \& Sedlaczek, 2010, p. 121-125; Ball \& Lindsay, 2013; Wilkinson, 2005; Klaassen, 2001; Vinke, 1995) and highlight the need for further research on the effect of EMDP participants' attainment of academic knowledge through a foreign medium (Shohamy, 2013, p. 202). Lecturers predominantly maintain a stance that English is the exclusive language of instruction, with German being used as an in-group language exclusively during student class work. Students, however, perceive the situation differently and report a large degree of code-switching between English and German within the classroom mainly due to a lack of sufficient English proficiency on the part of the teaching faculty. This assertion is supported by a lecturer who is of the opinion 
that many of the teaching faculty on the programme lack sufficient English proficiency to communicate the necessary content in their area of expertise. Furthermore, this respondent raises concerns about teaching faculty, in most cases, possessing lower English proficiency than the students they are teaching. This causes--what the respondent terms, an 'contamination' whereby students' English proficiency is negatively affected through interaction with teaching faculty lacking sufficient English proficiency. The respondent argues that considering the authority that teaching faculty embody, many students have a tendency to adopt similar linguistic features to their lecturers as they believe these to be the English to which they should aspire. This claim is also supported in the student data by one German student who explicitly addresses teaching faculty English proficiency and the effect of such on her English. While other students within Focus Group 1 do not verbalise their agreement with this statement, extra-linguistic nodding and tones of agreement were noted by the researcher. As this issue may be considered somewhat controversial and sensitive, this may explain many students' unwillingness to be explicitly vocal on the matter. Considering the complete dominance of German teaching faculty on the programme studied, the use of such features arguably has implications for their ability to communicate effectively with non-German speakers of English which may be seen to further perpetuate intelligibility issues in the environment:

Teaching faculty 02 (female): ...the problem is you have to make it simpler for the German students and even for some of the foreign students. You hear a lot of their English. After a while you get confused with what is English and what is German English. I feel they're maybe getting contaminated.

German student 16 (female): ...one thing I've been noticing is...(pause)...how our teachers' English can affect us. You hear them saying all of this wrong things in class...(pause)...and you think that's not English...(pause)...not like proper English. But then...(pause)...you catch yourself saying those things that the teachers say wrongly. (Pause)...it just kind of gets into you. You try to...(pause)...not do it but...(pause)...you just do it anyway. (Pause)...I don't think this should be happening. I want proper English or no English.

The use of German in the classroom in a code-switching capacity serves two functions. Firstly, switching between English and German provides teaching faculty with an important scaffolding tool not only as an additional means to deliver the content fully to their audience, but also to reinforce understanding amongst the German student population. Secondly, students report that code-switching to German from English occurs quite regularly when teaching faculty engage in social interactions within the classroom e.g. telling a joke, giving personal anecdotal 
evidence, administering discipline. This practice would indicate that German is employed as a tool for rapport building with students and as compensation for the diminished personality and authority which frequently results from utilising a foreign medium as the means of instruction by teaching faculty with limited proficiency (c.f. Ball \& Lindsay, 2013; Wilkinson, 2005; Klaassen, 2001). Considering that the population of the programme is predominantly comprised of international students with little or non-existent German proficiency, it is arguable that international students are being disadvantaged both educationally and socially as they are less able to establish rapport through the medium of English or receive additional clarification in their L1s. In exploring this issue, teaching faculty practices exhibit a complete lack of engagement and awareness of the use of German within the programme in spite of the significant issues it raises. In both questionnaire and interview data, teaching faculty, apart from the aforementioned respondent, maintain that, once the medium of instruction is predominantly English, any role that German plays is of no concern. This stance is reaffirmed by the perceived marginal role for German on the part of decision-makers, which is manifested in the provision of German as a foreign language support for international students on the programme.

Although DAAD guidelines stipulate that support services should be offered to international students, no requirements are set, as to what form they should take. This has allowed for multiple interpretations of the guidelines to emerge; and, as a result, many EMDPs in Germany do not offer any provision for German as a foreign language. In the context of this study site, German as a foreign language is offered; it is, however, only provided externally, at a basic level, unaccredited within the programme and at an additional cost to students. Paradoxically, however, other modern European languages such as Spanish and French are offered internally, at all proficiency levels, as an accredited component of the degree programme, and free of charge. As international students comprise the majority of the programme population with a ratio of 3:1 in comparison to German students, it is clear that the German language is of marginal importance to decision-makers and the programme's current language provision is unbalanced in favour of meeting the requirements of German students.

Many of the linguistic practices highlighted hitherto are grounded in strong ideologies about the roles of English and German within the setting, and their utility and functions in the Published in: Current Issues in Language Planning 15(2) 153-173 
macro environments of the university, German society and the globalised world. 'Ideology' refers to the beliefs that the members of a speech community attach to each language within their linguistic repertoires. With ideologies both deriving from and actively influencing ecology, they commonly form the basis for language policy action, either as a means of confirming or modifying a speech community's attitudes towards its languages (Spolsky, 2004, p. 14). *****

English uniformly holds high value in terms of 'symbolic capital' (Bourdieu, 1986) for students and teaching faculty within the environment studied. The high prestige that English currently holds as a language of academic communication is identified by all teaching faculty, and they directly relate English proficiency with an ability to remain up-to-date on the latest academic developments in their fields in addition to accessing a larger pool of educational material for their teaching in HE. Furthermore, they identify English proficiency as a key skill in career advancement in academia, this consideration providing a driving force for their willingness to teach through the medium of English. All attitudes towards, and motivations for, learning English amongst teaching faculty within the questionnaire data were purely extrinsic with many highlighting the role of English merely as a vehicle to communicate content to a multilingual, multicultural audience. They, therefore, stress the supremacy of the content rather than the medium through which it is transmitted within the environment:

Teaching faculty 01 (male): If you have all the literature in English you... (pause)...the natural flow of things is to talk about it in English...I like it this way and it's a different...it's broader thinking and if you do that...(pause)... the English language is the only carrier amm...(pause)... that can translate all the different aspects of the world

Teaching faculty 03 (female): English is just the vehicle...(pause)...you can transport all this information through English and because everyone speaks it...(pause)...it is easily understood. You cannot do that with a lot of other languages...(pause)...even German.

Amongst students, English holds equally high if not higher ideological value evidenced by $90 \%$ of students agreeing or strongly agreeing with the statements "English is an important international language" and "it is essential to be able to speak English nowadays". Many students directly equate English proficiency with employability and career success, with two thirds stating that the higher one's proficiency, the more successful one will become, which illustrates the high 
prestige and value of English as 'symbolic capital' (Bourdieu, 1986). Furthermore, utilising content and discourse analysis for qualitative questionnaire responses and focus group interactions it emerges that students identify the use of English within such an international programme of study as a means of developing skills to assist them in communicating internationally in their future careers and raising students' intercultural awareness. Students see great benefit in the composition of their study environment as their daily communication activity provides them with applied experience of communicating competently with a multilingual, multicultural group, thus preparing them for their future careers in international business. For German students, English is seen as providing the additional benefit of an international mindset which is frequently equated with cosmopolitanism and the positive associations connected to this. This view is repeatedly contrasted with equivalent German students studying through their L1 at the institution's Business Studies programme who are often described as "typically German" and closed-minded. This finding would indicate that English, therefore, functions as vehicle through which they can hedge the negative attributes of their German identity by means of an international outlook based on English:

International student 04 (male): ...from the education standpoint but from the social aspect it's extremely international...It opens you up to...(pause)...entirely new...(pause)...thoughts thought processes...(pause)... possibilities...(pause)...You see it allows you to be experienced to the other cultures.

German student 01 (female): ...you get to know a bit of their culture and...how you should behave with them...(pause)...and I think that's pretty important for the...(pause)...amm ...(pause)...daily life after studies so...because in work...(pause)...working in a global company you meet people from all over the world $\langle\mathrm{p}\rangle$ or at least you should...(pause)...know what or how you should behave with them.

German student 05 (female): ...like I see my friends at home...(pause)...I see that I sometimes think different than they do because I just...(pause)...I see so many other aspects...(pause)... which they don't see so $[. .$.$] they are really just German. They only...(pause)...see the German way of doing things. They are not$ open to ...(pause)....to other ways of looking at something or doing something. I'm not like that anymore.

German students ascribe a degree of authenticity to their study environment as representative of an international setting in which they intend to work through the medium of English. This internationality of their study environment, therefore, enables them to improve or maintain their English. International students, however, do not ascribe to this authenticity and see their EMDP pragmatically as facilitating study in Germany without prior knowledge of German.

Published in: Current Issues in Language Planning 15(2) 153-173 
The artificiality of the programme is based on international students' perception of insufficient English proficiency amongst the teaching faculty, a lack of interaction within their programme with English native speakers from the 'inner circle' (Kachru, 1985), and the inauthenticity of the learning environment due to lack of interaction between the German and international student groups:

International student 12 (female): I dunno...(pause)...I just expected more from the professors here. English is not a strength for them. They know their stuff...(pause)...but their English isn't always good enough. I really think we should have more native speakers from the UK...(pause)...America...(pause)...because they speak proper English. I miss it.

With regard to ideologies relating to German, a clear divide is identifiable between German students and teaching faculty members (i.e. all those of German origin), and international students. Teaching faculty see only a marginal role for German as a foreign language within the programme as means to survive in everyday life outside the programme, ignoring the role it plays in the daily linguistic practices of the speech community and its ideological value as integration capital. In spite of considering Germany an economic power, German students and teaching faculty exhibit negative attitudes towards the German language in terms of its utility, and its role as an international language and as an employable skill. This would indicate that they see a clear separation between the image of Germany as a country and the role of its language. This dichotomy between Germany's image as a country and the role of its language is supported by their awareness of an increasing tendency for the most influential firms in Germany to switch their working language to English, creating a diminished role for and interest in German. A further factor having a negative bearing on German, while equally having a positive bearing on English, is the perceived difficulty of the language. The perception of English as an easy language and German as difficult to learn filters through to linguistic practices in the form of low expectations on the part of German students in terms of communicative potential through the medium of German amongst international students further supporting a greater role for and interest in English. This is evidenced in the quantitative data where more than two thirds of German students strongly agree with the statement "it is important that international students from non-German-speaking countries learn German while studying in Germany". In the qualitative open-ended component to this questionnaire item, however, 
German students mitigate this requirement for German by highlighting the impediment that German's difficulty as a language poses to international students learning the language. All German students, therefore, state positivity towards international students learning German but only expect minimal proficiency from them and do not see German as a potential intercultural communication medium. While these groups express explicitly negative attitudes towards German, implicitly German maintains a prestige function within the study programme as a determiner of membership of the German group and a marker of integration in addition to serving a pragmatic purpose as a scaffolding tool within the classroom. Conversely, international students express predominantly positive attitudes towards German, recognising the pivotal role it plays in their integration while studying in Germany in addition to its role as a gatekeeper for group membership in the German student group. Additionally, many students express a strong desire to learn German on the grounds of employability given Germany's international economic standing:

German student 02 (male): Well I would see German and Germany as separate. Like Germany is an important country because we're very strong economically but German isn't important. You don't need it because...(pause)...well...(pause)...we can speak English and so does everyone else.

German student 03 (female): Well German is really hard to learn...(pause)...with all the cases and silly long words so like...(pause)...I wouldn't want people to have to learn it. I don't want to learn it.

International student 22 (male): Well I can see that German is a very important language. Germany is a big business country so it's great to speak their language. I see it in my home country...(pause)...there are German companies so maybe I can work there...(pause)...after studying here and learning German.

International student 17 (female): Economic power...(pause)...Germany is a big player so it's simple...(pause)...speak their language and you can be more successful.

By synthesising the complex ecology, ideology and planning ${ }^{\mathrm{x}}$ dimensions bearing on the EMDP under study discussed hitherto, a de facto language policy can be inferred, which should be considered for the formulation of an official language policy for this and similar programmes.

\section{Conclusion}

Published in: Current Issues in Language Planning 15(2) 153-173 
The findings of the case study presented herein provide important empirically-informed insights into the de facto realities of students and teaching faculty within an EMDP in Germany which may be useful to policymakers in formulating future policy within the area of EMDPs.. While the findings are the result of a single case study within the context of the German higher education system, they highlight a number of issues that both reflect the dominant themes in, and inform the debate surrounding, English-medium higher education in Germany and additional non post-colonial contexts e.g. Belgium, Denmark, Finland, Iceland, Norway, Sweden and the Netherlands.

Within the EMDP studied, it has been highlighted that English remains the primary language of instruction within the classroom; German, however, also plays a decisive role as a scaffolding tool, for rapport building in the environment, and as the de facto working language for German students in classroom interactions. This role for German needs to be acknowledged particularly with regard to the provision of German-as-a-foreign-language classes for international students to facilitate greater integration and mitigate any negative effect of English-German codeswitching on their learning experience. The achievement of a monolingual English-speaking environment would appear to be unattainable in view of the hierarchical use of languages for different communication purposes, in addition to the intelligibility issues previously highlighted. Any future policy should, therefore, be cognisant of the multilingual practices within the environment resulting from its multicultural composition, and the challenges and benefits associated with such. In spite of considerable impact it has upon the social and learning environment within the programme, the role of German in EMDPs has up to now not been explored by policymakers. Greater recognition and support for the role of German is required at top-down level to reap fully the benefits of the international, multicultural environment which such programmes create. With regard to English, policymakers need to acknowledge that English is not merely a neutral, uniform vehicle through which to transmit content, but rather varies quite significantly between nationality groups. The impact of the multiple varieties of English upon transmission of content, communication and interaction within the environment must be addressed by means of a greater emphasis on the language component of such programmes rather than solely focusing upon content transmission. 
The German Federal Government in 2000 set itself the aim of creating "a brain gain instead of a brain drain" (BMBF, 2000b, p. n.p.) through retaining German students, who ordinarily would have been lost to the English-speaking world, in addition to attracting international students away from the most popular international study locations, such as the USA and the UK, and retaining them after undergraduate or subsequent postgraduate study. It emerges within this study that positive attitudes towards English and German, particularly amongst international students, can co-exist. A decisive factor in creating a positive study experience for student group is the provision of adequate support in German as a foreign language alongside English within the programme. In light of the integral part that German plays in the social life both within and outside the programme and its facilitative role for integration, international students must be supported institutionally in their attempts to improve their proficiency in German. Only by becoming proficient in German and being assisted in integrating during their studies will it be possible for them to remain in Germany. Furthermore, German students highlight the missed opportunity for intercultural learning and the negative effect that a lack of integration within the programme is having on their environment and study experience. In view of the role that German plays as a gatekeeper denoting integration, an adequate provision of German-as-a-foreign-lanaguage instruction may have the dual effect of improving the study experience of both groups of students. In view of the lack of an official, written language policy, a comprehensive policy is required that takes account of the inner-workings of such a multicultural, multilingual environment investigated in this paper including a pragmatic appraisal of the roles of both English and German in such a setting so that sufficient resources can be dedicated to supporting the use of both languages by both students and teaching faculty.

\section{End notes}

${ }^{\mathrm{i}}$ The drawbacks identified by the German Science Council corresponded to (a) rigidity of the German traditional HE system, (b) curricular stagnation and a resultant lack of labour market relevance, (c) issues of comparability and compatibility with other HE systems, and (d) rigid German language requirements for study (Wahl, 2005).

ii The distinction is made in this paper between International Degree Programmes (IDPs) and English-medium degree programmes (EMDPs). The only difference between the terms is that the former includes programmes meeting the DAAD's criteria as an international programme where English is not a language of instruction while the latter describes $98 \%$ of all international programmes in Germany where English is either the partial or complete language of instruction. 
iii English-to-German phased programmes operate with English as the sole language of instruction in semester 1-3/4 with non-German-speaking students receiving intensive German as a foreign language training in order to transition to German as the language of instruction for the final semesters (i.e. 4/5-7/8).

iv These numbers represent $63 \%$ and $62 \%$ of the total population, respectively. At the time of data collection, the total student population within second and fourth semesters of the programme stood at 30 and 27 respectively, while the total faculty population stood at 8 for the programme.

$\checkmark$ In Germany, Fachhochschulen are Universities of Applied Sciences where the degree programmes follow an applied orientation emphasising the practical nature of study. The primary aim of such institutions is to prepare students for the labour market.

${ }^{v i}$ Here, the label 'international students' refers to students who have not completed their secondary education in Germany, but rather in their country of origin or a third country, and have decided to study at tertiary level in Germany.

${ }^{\text {vii }}$ A situation where predominantly OECD countries attempt to attract and retain the brightest minds, mainly from developing countries, in addition to stemming the emigration of domestic students (chiefly in favour of the English-speaking world), as a means of enhancing their national competitiveness.

viii This characterisation of native and non-native speakers follows students' characterisations which follows Kachru's categorisation of English speakers (1985). In students' viewnative speakers come solely from Kachru's (1985) inner circle, uncovering an element of linguistic purism on the part of students with regard to English varieties.

ix Although no official language policy exists for EMDPs in Germany in general, nor for the individual EMDP under investigation, the planning dimension in the model is important to acknowledge considering the interrelationship between the extra-linguistic frame within which EMDPs have developed and the effect such a frame has on the ideologies and practices of those involved on the programme under investigation and its implications for developing a de facto language policy for this and similar programmes.

${ }^{x}$ Although no official language policy exists for EMDPs in Germany in general, nor for the individual EMDP under investigation, the planning dimension in the model is important to acknowledge considering the interrelationship between the extra-linguistic frame within which EMDPs have developed and the effect such a frame has on the ideologies and practices of those involved on the programme under investigation and its implications for developing a de facto language policy for this and similar programmes.

\section{Note on Contributor}

Dr. Clive W. Earls is currently Assistant Lecturer in German \& Linguistics at Maynooth University, having recently completed his doctoral research as an Irish Social Sciences Platform (ISSP) Government of Ireland Scholar at the University of Limerick. His research interests include language policy and planning, sociolinguistics of English and German, intercultural communication, higher education policy studies. 


\section{References}

Baldauf, R. B. (1994). [Unplanned] Language policy and planning. Annual Review of Applied Linguistics, 14, 82-89.

Ball, P. \& Lindsay, D. (2013). Language demands and support for English-medium instruction in tertiary education. Learning from a specific context. In A. Doiz, D. Lasagabaster and J. M. Sierra (Eds.), English-medium instruction at universities (pp. 44-64). Bristol: Multilingual Matters.

Bourdieu, P. (1986). The forms of capital. In J. G. Richardson (Ed.), Handbook for theory and research for the sociology of education (pp. 241-258). New York: Greenwood Press.

Bundesministerium für Bildung und Forschung (BMBF) (2001). Bundesregierung wirbt weltweit um die besten Köpfe in der Wissenschaft [The Federal Government competes worldwide for the brightest minds in science], 22/2001 [press release], 27 February. Retrieved from http://www.bmbf.de/presse01/331.html

Bundesministerium für Bildung und Forschung (BMBF) (2000a). Grünes Licht für UMTS-Mittel für Bildung und Forschung [The green light for UMTS-income for education and research], 172/2000 [press release], 9 Nov. Retrieved from http://www.bmbf.de/presse01/251.htmlBundesministerium für Bildung und Forschung (BMBF) (2000b). Deutschland muss als Studienstandort international noch attraktiver werden [Germany must become more attractive as an international study location]. Retrieved from http://www.bmbf.de/presse01/62.html

Carnoy, M. (1994). Universities, technological change and training in the Information Age. In J. Salmi and A. M. Verspoor (Eds.), Revitalising higher education (pp. 41-98). New York: Pergamon.

Coleman, J. A. (2006). English-medium teaching in European higher education. Language Teaching, 39, 1-14.

Cooper, R. L. (1989). Language planning and social change. Cambridge: Cambridge University Press.

Cots, J. M. (2013). Introducing English-medium instruction at the University of Lleida, Spain: Intervention, beliefs and practices. In A. Doiz, D. Lasagabaster and J. M. Sierra (Eds.), English-medium instruction at universities (pp. 106-130). Bristol: Multilingual Matters.

Crystal, D. (1997). English as a global language. Cambridge: Cambridge University Press. 
DAAD (2011). International programmes in Germany. Retrieved from http://www.daad.de/deutschland/studienangebote/internationalprogrammes/07535.en.html

DAAD (2008). Qualität durch Internationalität: Das Aktionsprogramm des DAAD 2008-2011 [Quality through internationality. The DAAD action plan 2008-2011]. Retrieved from: http://www.daad.de/presse/de/aktionsprogramm_9_07_08.pdf

DAAD (2002). Internationale Studiengänge (Master-Plus und Auslandsorientierte Studiengänge): Zahlen und Fakten [International degree programmes (Master-Plus and internationally orientated degree programmes): Facts and Figures]. Berlin: DAAD.

DAAD and HRK (2001). Evaluation von Studiengängen des Demonstrationsprogramm "International ausgerichtete Studiengänge [Evaulation of degree progammes from the pilot programme "Internationally aligned degree programmes”]. Bonn: DAAD.

Doiz, A., Lasagabaster, D. and Sierra, J. (2011). Internationalisation, multilingualism and English-medium instruction. World Englishes, 30(3), 345-359.

Dollerup, C. (1996). English in the European Union. In R. Hartmann (Ed.), The English language in Europe (pp. 24-36). Exeter: Intellect.

Dunst, D. (2005). Internationale Studiengänge an der Technischen Universität HamburgHarburg. In M. Motz (Ed.), Englisch oder Deutsch in Internationalen Studiengängen? [English or German in international degree programmes?] (pp. 89-98). Frankfurt am Main: Peter Lang.

Europa (2011) Gateway to the European Union: Germany. Retrieved from http://europa.eu/about-eu/countries/member-countries/germany/index_en.htm

Fandrych, B. and Sedlaczek, B. (2010). "I need German in my life": Eine empirische Studie zur Sprachsituation in englischsprachigen Studiengängen in Deutschland ["I need German in my life": An empirical study on the language situation in English-medium degree programmes in Germany]. Tübingen: Stauffenburg Verlag.

Fishman, J. (1988). The new linguistic order. Foreign Policy, 113, 26-32 \& 34-40.

Gillham, B. (2000). Developing a questionnaire. London: Continuum.

Graddol, D. (1997). The Future of English? Retrieved from http://www.britishcouncil.org/learning-elt-future.pdf 
Haarmann, H. (1990). Language planning in the light of a general theory of language: A methodological framework. International Journal of Sociology and Language, 86, 103126.

Hagège, C. (1996). Welche Sprache für Europa? Verständigung in der Vielfalt [Which language for Europe? Understanding in diversity]. Frankfurt: Campus.

Harlech-Jones, B. (1990). You taught me language: The implementation of English as a medium of instruction in Namibia. Oxford: Oxford University Press.

Haugen, E. (1971). The ecology of language. The Linguistic Reporter Supplement, 25, 19-26.

Heller, M. (2010). The Commodification of Language. Annual Review of Anthropology, 39, 101114.

Heller, M. (2003). Globalization, the new economy and the commodification of language and identity. Journal of Sociolinguistics, 7(4), 473-492.

Hellmann, J. and Pätzold, M. (2005). Internationale Studiengänge: Wer braucht so etwas? Überlegungen zu einem Trend, der sich fortsetzen wird. In M. Motz (Ed.), Englisch oder Deutsch in Internationalen Studiengängen? [English or German in international degree programmes?] (pp. 17-30). Frankfurt am Main: Peter Lang.

Hoffmann, C. (2000). The spread of English and the growth of multilingualism with English in Europe. In J. Cenoz and U. Jesnner (Eds.), English in Europe - Acquisition of a third language (pp. 1-21). Clevedon: Multilingual Matters.

Hughes, R. (2008). Internationalisation of higher education and language policy questions: Questions of quality and equity. Higher Education Management and Policy, 20(1), 111128.

Hüppauf, B. (2004). Globalization - Threats and opportunities. In A. Gardt and B. Hüppauf (Eds.) Globalization and the future of German (pp. 3-24). Berlin: Mouton de Gruyter.

International Monetary Fund (2011). Report for selected countries and subjects. Retrieved from http://www.imf.org/external/pubs

Kachru, B. B. (1985). Standards, codification and sociolinguistic realism: The English language in the outer circle. In R. Quirk and H. Widdowson (Eds.), English in the world: Teaching and learning the language and literatures (pp. 11-36). Cambridge: Cambridge University Press. 
Klaassen, R. G. (2001). The international university curriculum. Challenges in English-medium Engineering education. Delft: Delft University of Technology.

Krishnamurti, B. H. (1990). The regional language vis-à-vis English as a medium of instruction in higher education: The Indian dilemma. In D. Prasanna Pattanayak (Ed.), Multilingualism in India (pp. 15-24). Clevedon: Multilingual Matters.

Lub, A., Van Der Wende, M., and Witte, J. (2003). Bachelor-Master Programmes in the Netherlands and Germany. Tertiary Education and Management, 9, 249-266.

Maiworm, F., \& Wächter, B. (2008). English-language-taught degree programmes in European higher education. Bonn: Lemmens.

Marginson, S. \& Van der Wende, M. (2006). Globalisation and higher education. Retrieved from http://www.oecd.org/dataoecd/20/4/37552729.pdf

Marsh, D., \& Laitinen, J. (2005). Medium of instruction in European higher education: Summary of research outcomes of European Network for Language Learning Amongst Undergraduates (ENLU) Task Group 4. Jyväskylä: UniCOM.

Merriam, S. B. (2001). Qualitative research and case study applications in education. San Francisco: Jossey-Bass Publishers.

Naidoo, R. (2003). Repositioning higher education as a global commodity: Opportunities and challenges for future sociology of education work. British Journal of Sociology of Education, 24(2), 249-259.

Naidoo, R., and Jamieson, I. (2005). Knowledge in the marketplace: The global commodification of teaching and learning in higher education. In P. Ninnes and M. Hellstén (Eds.), Internationalizing higher education (pp. 37-51). The Netherlands: Springer.

Netherlands organization for international cooperation in higher education. (Nuffic) (2011) International study programmes in the Netherlands. Retrieved from http://www.nuffic.nl/international-students

Parlett, M., and Hamilton, D. (1972). Evaluation as illumination: A new approach to the study of innovatory programmes. In D. Tawney (Ed.), Curriculum evaluation today: Trends and implications (pp. 84-101). London, MacMillan.

Patton, M. Q. (2002). Qualitative evaluation and research methods $\left(2^{\text {nd }}\right.$ ed.). Thousand Oaks, California: Sage, $2^{\text {nd }}$ Edition. 
Powell, R., McGuire, S., and Crawford, G. (1999). Convergence of student types: Issues for distance education. In A. Tait and R. Mills (Eds.), The convergence of distance and conventional education: Patterns of flexibility for the individual learner (pp. 86-99). Routledge: London.

Rahman, T. (2009). Language ideology, identity and the commodification of language in the call centres of Pakistan. Language in Society, 39, 233-258.

Rickwood, P., and Goodwin, V. (1999). A worthwhile education?. In A. Tait and R. Mills (Eds.) The convergence of distance and conventional education: Patterns of flexibility for the individual learner (pp. 110-123). Routledge: London.

Schwarz-Hahn, S., and Rehburg M. (2003). Bachelor and Master in Deutschland: Empirische Befunde zur Studienstrukturreform. Kassel: Wissenschaftliches Zentrum für Berufs- und Hochschulforschung.

Seidlhofer, B., Breiteneder, A., and Pitzl, M. L. (2006). English as a lingua franca in Europe: Challenges for Applied Linguistics. Annual Review of Applied Linguistics, 26, 3-34.

Shohamy, E. (2013). A critical perspective on the use of English as a medium of instruction at universities. In Doiz, A., Lasagabaster, D. and Sierra, J. M. (Eds.) English-medium instruction at universities (pp. 196-213). Bristol: Multilingual Matters.

Shohamy, E. (2009). Language policy as experiences. Language Problems and Language Planning, 33(2), 185-189.

Shohamy, E. (2006). Language policy: Hidden agendas and new approaches. London, Routledge.

Spolsky, B. (2004). Language policy. Cambridge: Cambridge University Press.

Statistisches Bundesamt (2011). Bildung und Kultur: Allgemeinbildende Schulen 2010/2011 [Education and culture: Schools of general education 2010/2011]. Wiesbaden: Statistisches Bundesamt.

Statistisches Bundesamt (Federal Bureau of Statistics) (2008a). Allgemeinbildende Schulen Schüler/innen nach Schularten [Schools of general education - Students by school type]. Wiesbaden: Statistisches Bundesamt.

Statistisches Bundesamt (Federal Bureau of Statistics) (2008b). Allgemeinbildende Schulen: Schüler/innen mit fremdsprachlichem Unterricht [Schools of general education: Students learning foreign languages]. Wiesbaden: Statistisches Bundesamt. 
Stenhouse, L. (1988). Case study methods. In J. P. Keeves (Ed.), Educational research, methodology, and measurement: An international handbook (pp. 49-53). Oxford: Pergamon.

Study in Sweden. (2011) Degree program database. Retrieved from http://www.studyinsweden.se/Course-search/

Tsui, A. B. M. (2008). Medium of instruction in Hong Kong: One country, two systems, whose language?. In J. W. Tollefson and A. B. M. Tsui (Eds.), Medium of instruction policies. Which agenda? Whose agenda? (pp. 97-116). Mahwah, NJ: Lawrence Erlbaum.

Tung, P., Lam, R. and Tsang, W. K. (1997). English as a medium of instruction in post-1997 Hong Kong: What students, teachers and parents think. Journal of Pragmatics, 28(4), 441-459.

Uys, M., Van der Walt, J., Van den Berg, R. And Botha, S. (2007). English medium of instruction: A situational analysis. South African Journal of Education, 27(1), 69-82.

Vinke, A. A. (1995). English as the medium of instruction in Dutch Engineering education, Delft: Delft University of Technology.

Voegeli, W. (2005). Internationale Studiengänge an der Hamburger Universität für Wirtschaft und Politik. In M. Motz (Ed.), Englisch oder Deutsch in Internationalen Studiengängen? [English or German in international degree programmes] (pp. 99-109). Frankfurt am Main: Peter Lang.

Wahl, U. (2005). Internationalisierung der Hochschulen - Ein Deutschproblem. In M. Motz (Ed.), Englisch oder Deutsch in Internationalen Studiengängen? [English or German in international degree programmes] (pp. 31-37). Frankfurt am Main: Peter Lang.

Wilkinson, R. (2008). Locating the ESP space in problem-based learning: English-medium degree programmes from a post-Bologna perspective. In I. Fortanet-Gomez and C. Räisänen (Eds.), ESP in European higher education (pp. 55-73). Amsterdam: John Benjamins.

Wilkinson, R. (2005). The impact of language on teaching content: Views from the content teacher. Maastricht: Maastricht University.

Wissenschaftsrat (1966). Empfehlungen zur Neuordnung des Studiums an wissenschaftlichen Hochschulen [Recommendations on the educational reform of higher education institutions]. Bonn: Wissenschaftsrat. 


\footnotetext{
${ }^{\mathrm{i}}$ The drawbacks identified by the German Science Council corresponded to (a) rigidity of the German traditional HE system, (b) curricular stagnation and a resultant lack of labour market relevance, (c) issues of comparability and compatibility with other HE systems, and (d) rigid German language requirements for study (Wahl, 2005).

ii The distinction is made in this paper between International Degree Programmes (IDPs) and English-medium degree programmes (EMDPs). The only difference between the terms is that the former includes programmes meeting the DAAD's criteria as an international programme where English is not a language of instruction while the latter describes $98 \%$ of all international programmes in Germany where English is either the partial or complete language of instruction.

iii An internationalised curriculum pertains to the orientation of the subject matter around international standards and practices, and the use of methodologies and theoretical insights from other academic cultures.

iv English-to-German phased programmes operate with English as the sole language of instruction in semester 1-3/4 with non-German-speaking students receiving intensive German as a foreign language training in order to transition to German as the language of instruction for the final semesters (i.e. 4/5-7/8).

$\mathrm{v}$ These numbers represent $63 \%$ and $62 \%$ of the total population, respectively. At the time of data collection, the total student population within second and fourth semesters of the programme stood at 30 and 27 respectively, while the total faculty population stood at 8 for the programme.

vi In Germany, Fachhochschulen are Universities of Applied Sciences where the degree programmes follow an applied orientation emphasising the practical nature of study. The primary aim of such institutions is to prepare students for the labour market.

vii Here, the label 'international students' refers to students who have not completed their secondary education in Germany, but rather in their country of origin or a third country, and have decided to study at tertiary level in Germany.

viii A situation where predominantly OECD countries attempt to attract and retain the brightest minds, mainly from developing countries, in addition to stemming the emigration of domestic students (chiefly in favour of the Englishspeaking world), as a means of enhancing their national competitiveness.

ix This characterisation of native and non-native speakers follows students' characterisations which follows Kachru's categorisation of English speakers (1985). In students' viewnative speakers come solely from Kachru's (1985) inner circle, uncovering an element of linguistic purism on the part of students with regard to English varieties.
}

$\mathrm{x}$ Although no official language policy exists for EMDPs in Germany in general, nor for the individual EMDP under investigation, the planning dimension in the model is important to acknowledge considering the interrelationship between the extra-linguistic frame within which EMDPs have developed and the effect such a frame has on the ideologies and practices of those involved on the programme under investigation and its implications for developing a de facto language policy for this and similar programmes. 